\title{
Improvement of $3 R$ waste treatment creativity In basic education in Medan
}

\author{
Nurman Achmad $^{1 *}$, Devin Defriza Harisdani ${ }^{2}$, Dwi Lindarto Hadinugroho ${ }^{1}$ \\ ${ }^{1}$ Department Sosial Anthropology Faculty of Engineering Universitas Sumatera Utara, \\ Medan, Indonesia \\ ${ }^{2}$ Department of Architecture Faculty of Engineering Universitas Sumatra Utara, Medan, \\ Indonesia \\ *Email: nurman@usu.ac.id
}

\begin{abstract}
One important resource at the level of basic education is human resources which requires increased selfcompetence complementing life skills interrupted by the main tasks as teaching educators. MIS Islamiyah Sunggal School, Medan with the foundation's social mission focuses on serving the average disadvantaged community around the school. The condition of such limited sources of funds requires an alternative way of creating an entrepreneurial spirit to increase income for school educators. For this purpose the 2019 USU TALENTA Community Service Team was conducted directly in the field with community involvement and university lecturers from the University of North Sumatra. The training is carried out with recycling activities and enhancing the $3 \mathrm{R}$ waste treatment creativity skills in basic education. It is expected to be able to overcome environmental pollution and open up new opportunities for the community to open up new jobs. In addition to overcoming environmental problems, it also advances the nation economically thereby reducing the number of unemployed people in this country.
\end{abstract}

Keyword: 3R Waste Treatment, Recycling, Creativity, Economic Revenue

\begin{abstract}
Abstrak
Salah satu sumber daya penting di tingkat pendidikan dasar adalah Sumber Daya Manusia yang memerlukan peningkatan kompetensi diri melengkapi kecakapan hidup disela tugas pokok sebagai pengajar pendidik. Sekolah MIS Islamiyah Sunggal, Medan dengan misi sosial yayasan memfokuskan diri pada pelayanan masyarakat rata-rata kurang mampu di sekitar sekolah. Kondisi sumber dana yang terbatas demikian menuntut adanya alternatif penciptaan jiwa kewirausahaan guna peningkatan pendapatan bagi para pendidik sekolah. Untuk tujuan inilah dilakukan kegiatan Pengabdian pada Masyarakat TALENTA USU 2019 dilakukan langsung di lapangan dengan pelibatan masyarakat dan dosen perguruan tinggi dari Universitas Sumatera Utara. Pelatihan dilakukan dengan kegiatan daur ulang dan peningkatan keterampilan kreatifitas pengolahan limbah $3 \mathrm{R}$ pada pendidikan dasar ini diharapkan dapat mengatasi pencemaran lingkungan dan membuka peluang baru bagi masyarakat untuk membuka lapangan pekerjaan baru. Selain mengatasi masalah lingkungan juga turut memajukan bangsa secara ekonomi sehingga mengurangi jumlah pengangguran di negeri ini..
\end{abstract}

Kata Kunci: Pengolahan Limbah 3R, Daur Ulang, Kreativitas, Pendapatan Ekonomi

\section{PENDAHULUAN \\ 1.1Analisis Situasi}

Salah satu sumber daya penting di tingkat pendidikan dasar adalah Sumber Daya Manusia yang memerlukan peningkatan kompetensi diri melengkapi kecakapan hidup disamping tugas pokok sebagai pengajar pendidik. Sekolah MIS Islamiyah Sunggal Medan (Gambar 1), adalah salah satu pelaku pendidikan tingkat dasar yang didirikan dengan misi sosial yayasan terfokus pada pelayanan bagi masyarakat kurang mampu di lingkungan Kelurahan Sunggal Medan dan sekitarnya. Falsafah pendidikan dasar berbasis sosial demikian mempunyai konsekuensi terhadap 
pengelola dalam kondisi sumber dana yang hanya mengandalkan dana SPP, dana BOS dan dana donatur terbatas yang berakibat minimnya tingkat apresiasi honor, gaji dan upah para guru sekolah. Masalah tersebut menuntut adanya alternatif penciptaan jiwa kewirausahaan dengan tujuan peningkatan pendapatan bagi para guru sekolah.

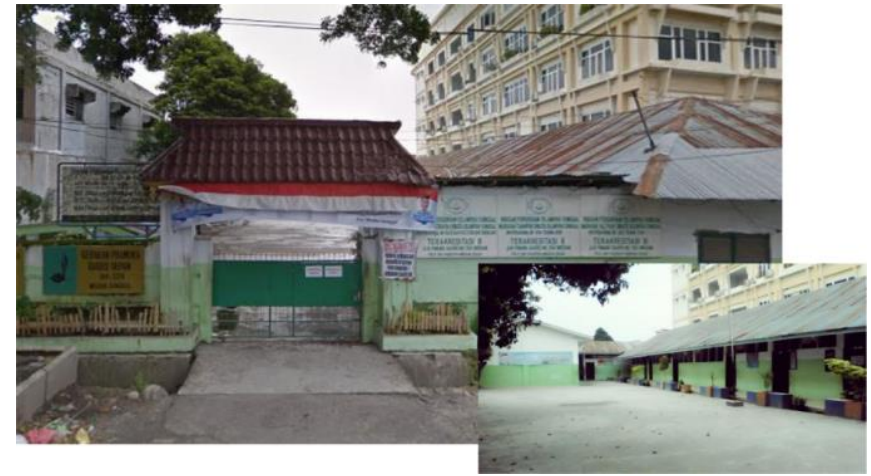

Gambar 1.1 Kondisi Eksisting MIS Islamiyah Sunggal, Kota Medan

\subsection{Permasalahan Mitra}

Masalah yang dihadapi para guru MIS Islamiyah Sunggal Medan adalah kurangnya kemampuan ketrampilan para guru dalam pengembangan jiwa wirausaha yang mampu digunakan sebagai upaya alternatif peningkatan pendapatan meningkatkan kesejahteraan keluarga.

Dalam beberapa literatur maupun artikel kewirausahaan banyak dikemukakan nilai nilai yang terkandung dalam jiwa kewirausahaan antara lain kreatif dan inovatif, mampu melihat dan memanfaatkan peluang, mampu bekerjasama, memiliki motivasi yang tinggi, kerja keras, berani menghadapi risiko, percaya diri yang tinggi, berorientasi pada tugas dan hasil, memiliki jiwa pemimpin, optimis, memiliki komitmen, proaktif (Zimmerer, 2008; Arief, 2006). Nilai-nilai tersebut menjadi materi yang akan di-transfer-kan pada Abdimas ini dengan cara praktek langsung atau belajar memecahkan permasalahan atas rendahnya pengetahuan dan keterampilan pendidik dan peserta didik pada MIS Islamiyah Sunggal Medan ini.

Sejalan pula dengan profil dari MIS Islamiyah ini, menuju akreditasi berikutnya dan akan mengembangkan sarana prasarana ramah lingkungan di antaranya bank sampah, pengomposan, pemanfaatan tempat sampah terpilah, daur ulang sampah/limbah dan sarana ramah lingkungan lainnya dalam menanggulangi permasalahan lingkungan di sekolah maka diperlukan sebuah aksi dalam dalam menuju predikat Sekolah Adiwiyata.

\section{METODE PELAKSANAAN}

Metode pelaksanaan dari kegiatan Pengabdian Pada Masyarakat (Abdimas) ini adalah kegiatan pelatihan dan simulasi yang dilaksanakan bersama mitra. Adapun metoda pengabdian ini berupa pembelajaran experiental learning. Experiential learning theory (ELT) dikembangkan oleh David Kolb sekitar awal 1980-an (Kolb, 1999). Model ini menekankan pada sebuah model pembelajaran yang holistik dalam proses belajar. Dalam experiential learning, pengalaman mempunyai peran sentral dalam proses belajar. Istilah "experiential" di sini untuk membedakan antara teori belajar kognitif yang cenderung menekankan kognisi lebih daripada afektif. Experiential learning dapat didefinisikan sebagai tindakan untuk mencapai sesuatu berdasarkan pengalaman guna meningkatkan keefektifan dari hasil belajar itu sendiri.

Tujuan model ini adalah untuk mempengaruhi pembelajar dengan tiga cara, yaitu; 1) mengubah struktur kognitif, 2) mengubah sikap, dan 3) memperluas keterampilan-keterampilan yang telah ada. Adapun aspek kewirausahaan yang menekankan pada Knowledge (pengetahuan), Skills (keterampilan), dan Attitude (sikap), atau sering disingkat KSA, dapat diajarkan melalui 
proses pendidikan, namun demikian tidak semua aspek kewirausahaan dapat diajarkan dengan perspektif pembelajaran yang sama menurut Albornoz (2008). Alasan inilah yang memperkuat pentingnya model experiential learning (pengalaman langsung) dalam pembelajaran kewirausahaan.

Terkait dengan perlunya praktek langsung dinyatakan bahwa: People develop skills, expertise and social contacts from their work, often as Employees gaining experience, understanding and know-how of how an industry works. This learning is social and relational, gained from interpersonal participation through discovery and experience. It is often functional, technical and problem solving in nature, finding out how things are done through the failures and experiences and mentoring of the more experienced (Kellet, 2006). Dengan demikian kegiatan pengabdian pada masyarakat ini bertujuan untuk mengatasi masalah peningkatan keterampilan, meningkatkan kewirausahaan dengan cara pengalaman praktek langsung (praktek mikro). Metode operasional yang dijalankan adalah berbagi informasi (information sharing), belajar dari pengalaman (experience based), pemecahan masalah (problem solving based).

\section{HASIL DAN PEMBAHASAN}

Target pengabdian pada masyarakat ini adalah pelatihan singkat tentang pengetahuan kewirausahaan untuk mengatasi masalah tersebut diatas yang secara bertahap menambah pengetahuan (knowledge) dalam serangkaian praktik kewirausahaan dan menambah ketrampilan (skill) melalui pengolahan limbah 3R (Reduce, Reuse dan Recycle) menjadi produk olahan seni memanfaatkan daur ulang limbah rumah tangga yang sekaligus dapat dimanfaatkan sebagai bahan pembelajaran oleh guru sebagai modul bahan ajar pendidikan berbasis lingkungan hidup.

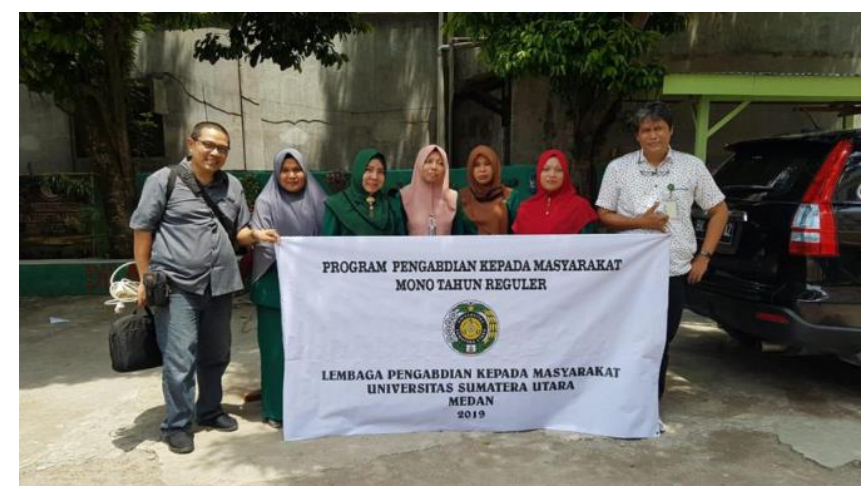

Gambar 3.1 Lokasi Abdimas, MIS Islamiyah Sunggal, Kota Medan

Simulasi dan praktek mikiro daur ulang ini dilakukan untuk dapat mengatasi pencemaran lingkungan dan membuka peluang baru bagi masyarakat untuk membuka lapangan pekerjaan baru. Selain mengatasi masalah lingkungan juga turut memajukan bangsa secara ekonomi sehingga mengurangi jumlah pengangguran di negeri ini. Abdimas ini melakukan kegiatan daur ulang, keterampilan kreatifitas pengolahan limbah 3R pada pendidikan dasar di Medan. 


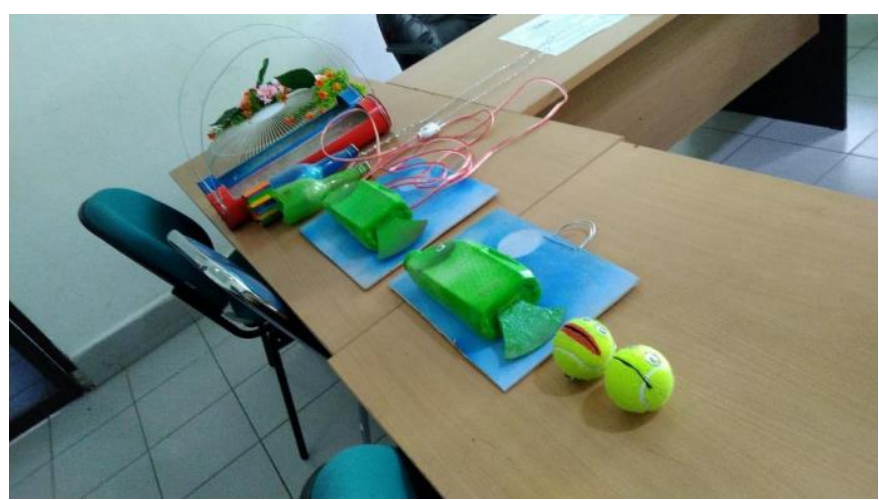

Gambar 3.2 Aplikasi daur ulang limbah plastik dan lainnya

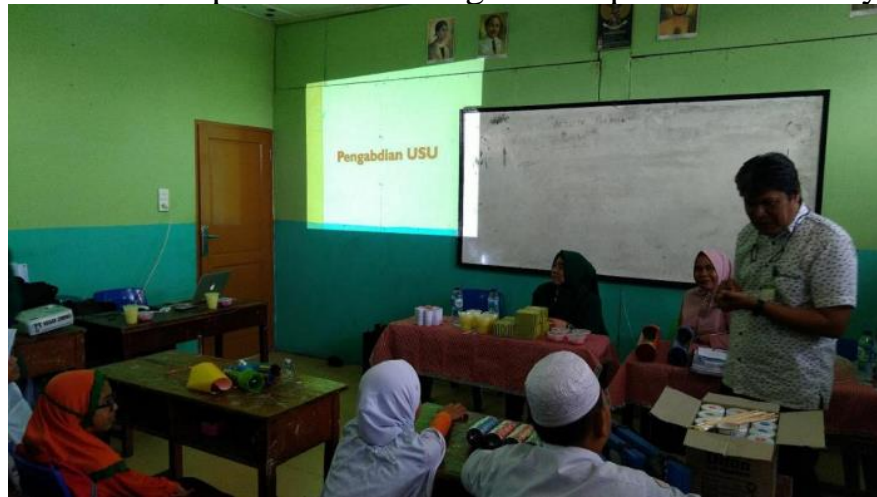

Gambar 3.3 Pemberian pemahaman kewirausahaan dan edupreneurship

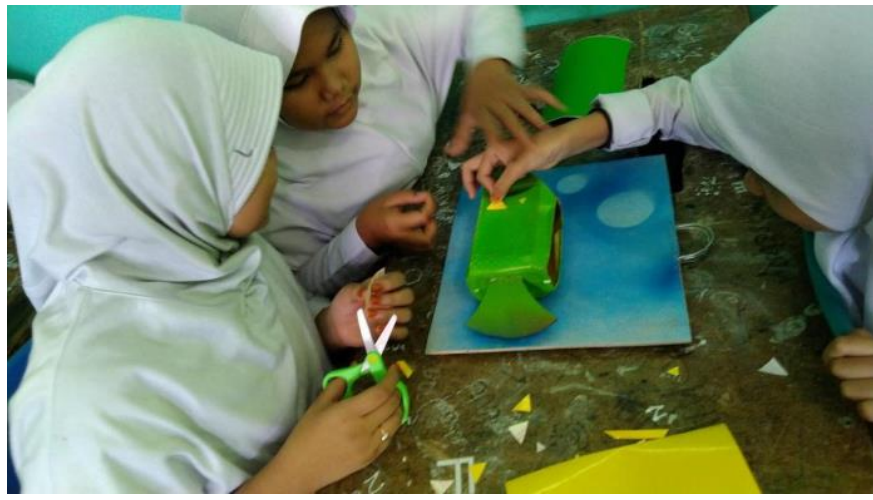

Gambar 3.4 Pemberian pemahaman kreatif praktek mikro keterampilan pengolahan limbah 3R

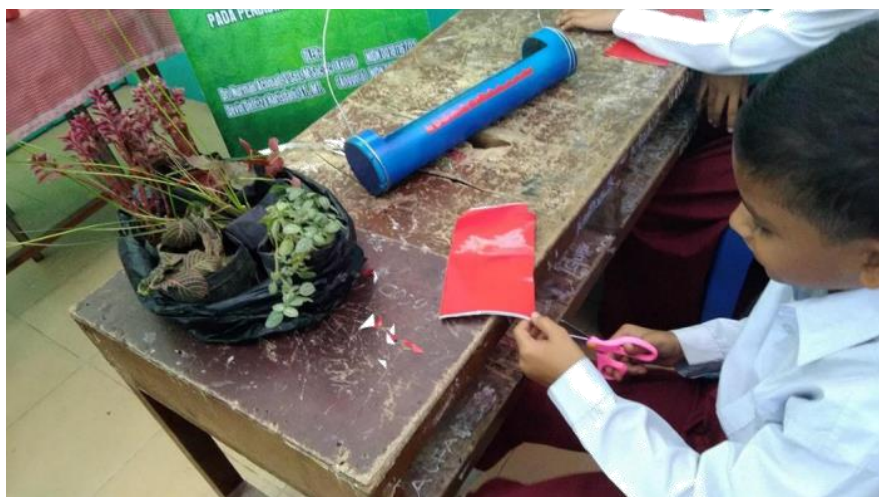

Gambar 3.5 Pemberian pemahaman teknis praktek mikro keterampilan pengolahan limbah 3R 


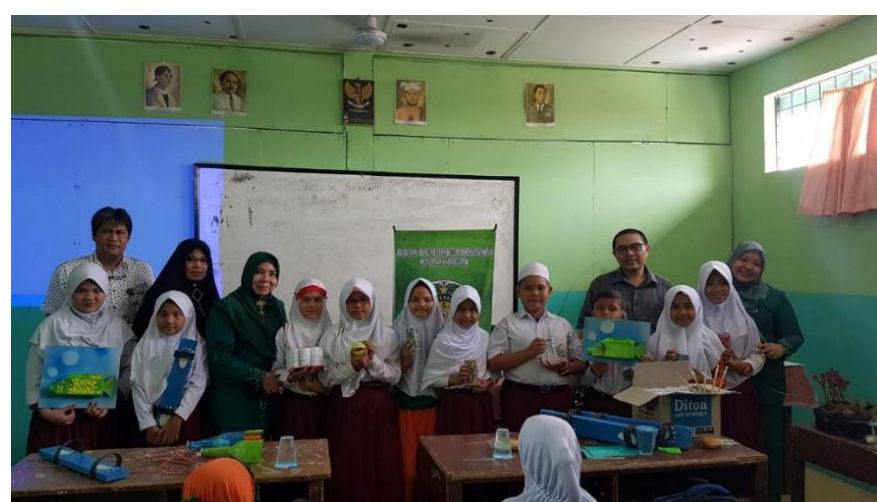

Gambar 3.6 Suasana praktek mikro keterampilan pengolahan limbah 3R

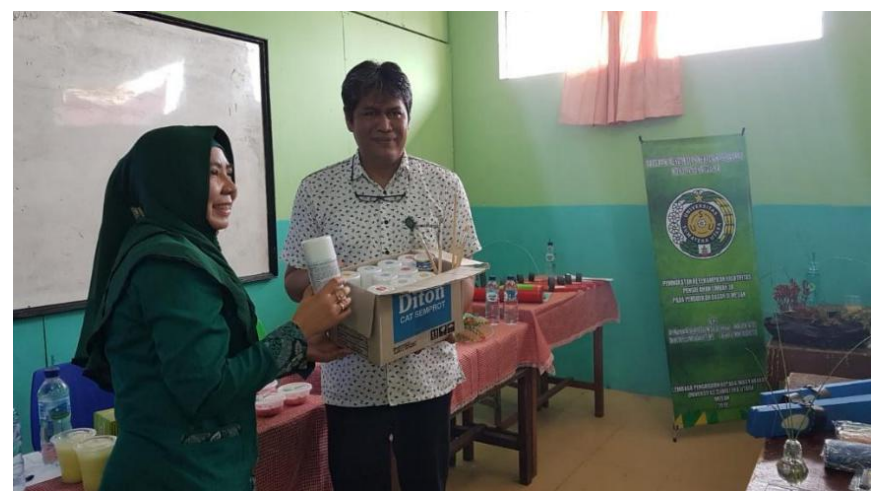

Gambar 3.7 Penyerahan peralatan keterampilan pengolahan limbah 3R kepada mitra

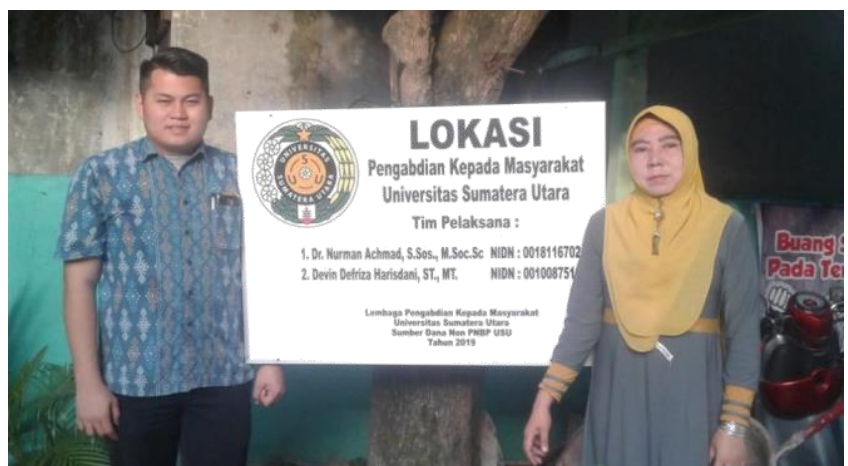

Gambar 3.8 Mitra dan sign kegiatan di lokasi

\section{KESIMPULAN}

\subsection{Kesimpulan}

Wujud kegiatan ini merupakan kemitraan bekerja sama dalam pelatihan ketrampilan meliputi pemahaman, motivasi, kreatifitas, teknik pendanaan dan teknik marketing berbasis kewirausahaan yang dipraktekkan melalui kegiatan ketrampilan mengolah limbah 3R menghasilkan kreasi yang sekaligus dapat dimanfaatkan sebagai bahan pembelajaran oleh guru sebagai modul bahan ajar pendidikan berbasis lingkungan hidup. Hasil pelatihan dan simulasi ini mampu menjadi alternatif berwirausaha meningkatkan pendapatan bagi para guru pendidik, bahan ajar menarik terutama bagi sekolah yang berpredikat Sekolah Adiwiyata, serta berperan sebagai alternatif bagi pemecahan masalah limbah bagi lingkungan hidup

\subsection{Saran}

Perlunya dilakukan pemantauan dan pendampingan berkelanjutan dalam transfer knowledge and skill ilmu pengetahuan praktis mengatasi permasalahan mitra secara komprehensif untuk 
mengatasi masalah peningkatan ketrampilan wirausaha, meningkatkan pendapatan dengan cara peningkatan keterampilan guru pendidik melalui pelatihan dan simulasi iptek lainnya dengan dilengkapi pelaksanaan praktek mikro di lapangan.

\section{UCAPAN TERIMAKASIH}

Tim Pengabdi mengucapkan terima kasih kepada Lembaga Pengabdian Pada Masyarakat (LPPM) Universitas Sumatera Utara yang telah Memberikan dana dengan skema mono tahun 2019, Nomor : 327/UN5.2.3.2.1/PPM/2019, Tanggal 20 Mei 2019. Ucapan terima kasih juga disampaikan kepada mitra yang membantu terlaksananya kegiatan ini.

\section{DAFTAR PUSTAKA}

Albornoz, C. A. (2008). Toward A Set of Trainable Content on Entrepreneurship Education: A Review of Entrepreneurship Research From Educational Prespective. J. Technol. Manag. Innov. 2008. Volume 3, Special Issue 1: 86-98. (www.jotmi.org/index.php/GT/article/viewFile/rev5/131-).

Arief, Zainal A. (2006), "Model Pembelajaran Kewirausahaan Berbasis Pada Konsep Academic Business Community “, (www.isjd.pdii.lipi.go.id/admin/jurnal/1610642.56/pdf)

Kellet, S. (2006). A Picture of Creative Entrepreneurship: Visual Narrative in Creative Entreprise Education. (online) (http://www.ncge.com/files/biblio 1002.pdf)

Kolb, A.D. \& Boyatzis, R.E. (1999). Experiential Learning Theory, Previous Research and New Direction. Case Western Reserve University.

Zimmerer, W. Thomas dan Norman M Scharborough (2008). "Kewirausahaan dan Manajemen Usaha Kecil“", Jakarta : Penerbit Salemba Empat 